\title{
PERFORMANCE OF LOW AGRICULTURAL TUNNELS FOR VEGETABLES PRODUCTION
}

\author{
Ragab, I. Murad ${ }^{1}$, Hassan, M. F. ${ }^{3}$, \\ Abdel-Wahed, M. H. ${ }^{2}$ and Raslan M. A. ${ }^{4}$
}

\begin{abstract}
Low agricultural tunnels were used for controlling in environmental conditions surrounding plants to provide suitable climate and to maximize the agricultural productivity. In this research, the low agricultural tunnels are proposed for testing the factors, which evaluated the tunnel performance, these factors were: tunnel covers thickness (40, 50 and 65 micron), number of layers tunnel cover (single and double), soil surface cover type (bare soil, black plastic mulched and rice straw), the solar radiation $\left(\mathrm{w} / \mathrm{m}^{2}\right.$. day), the ambient air temperature $\left({ }^{\circ} \mathrm{C}\right)$, inner tunnel temperature $\left({ }^{\circ} \mathrm{C}\right)$, inner tunnel relative humidity (\%) and the soil surface temperature $\left({ }^{\circ} \mathrm{C}\right)$. The tunnel performance was evaluated in respect of the Cucurbita productivity and the tunnel thermal efficiency. The proposed low tunnel was studied by the thermal behavior inside the tunnel and study of thermal equilibrium under different circumstances. The maximum productivity was investigated with the following conditions: black plastic mulched double layer tunnel cover and 50 micron of cover thickness.
\end{abstract}

Keywords: Low agricultural tunnel, Environmental condition, Performance, Heat transfer, Plastic mulch, Rice straw.

\section{INTRODUCTION}

bout $95 \%$ of plants, either food crops or cash crops are grown in
open field. Since time immemorial, man has learnt how to grow
plants under natural environmental conditions. In some of the temperate regions where the climatic conditions are extremely adverse and no crops can be grown, man has developed methods of growing some high value crop continuously by providing protection from the excessive cold, which is called as greenhouse technology.

\footnotetext{
${ }^{1}$ Prof., Agric. Eng. Dept., Fac. of Agric., Alexandria Univ., Matrouh Branch, Egypt.

${ }^{2}$ Prof., Agric. Eng. Dept., Fac. of Agric., Fayoum Univ., Egypt.

${ }^{3}$ Lecturer, Agric. Eng. Dept., Fac. of Agric., Fayoum Univ., Egypt.

${ }^{4}$ Agricultural engineer in Shoura Chemicals Company.
} 
So, greenhouse technology is the technique of providing favorable environment condition to the plants. It is rather used to protect the plants from the adverse climatic conditions such as wind, cold, precipitation, excessive radiation, extreme temperature, insects and diseases. It is also of vital importance to create an ideal micro climate around the plants. This is possible by erecting a greenhouse/glass house, where the environmental conditions are so modified that one can grow any plant in any place at any time by providing suitable environmental conditions with minimum labor (Kaiser and Ernst, 2012). Many researchers did many studies on agricultural operations within greenhouses, and they dealt with many of the factors affecting productivity within those greenhouses (Elsner et al. 2000). Tunnel design, dimensions, and construction materials all have an impact on the structure's use and performance (Kaiser and Ernst, 2012). Tunnels, also known as hoop houses, are relatively simple polyethylenecovered greenhouse-like structures built over ground beds, provide protection from unfavorable weather conditions, including wind, hail, frost, and excessive rainfall (Kaiser and Ernst, 2012). This can help improve the survival rate of perennial crops, as well as result in faster plant growth, higher yields, improved produce quality, fewer culls, and more marketable produce for many crops. Insect and disease problems are often less severe in a high tunnel; fewer pests can mean improved organic production potential. High tunnels also provide a sheltered environment for laborers during planting, production, and harvest operations (Elsner et al. 2000). Greenhouses are highly sophisticated structures, which aim at providing ideal conditions for satisfactory plant growth and production throughout the year. The growth factors such as light, temperature, humidity and air composition should be delivered and maintained at optimal levels.

Transparent covering of the greenhouse allows the shortwave solar radiation to enter but it is partially opaque to the long wave radiation resulting in the greenhouse effect. In cold climates or seasons, higher inside air temperature is desirable during all hours for maximum plant growth and that can be achieved by keeping the greenhouse closed for maximum greenhouse using any suitable heating system. Abdel-Ghany and Al-Helal (2011) mentioned that, approximately $95 \%$ of the 
greenhouses in Egypt are mainly covered with plastic film, and almost all of them are used for vegetable crops production. Abou-Hadid (2000) reported that, a large quantity of plastics is used annually world-wide in the agricultural sector, of which a significant amount is intended for protected cultivation, in greenhouses and low tunnels. For this specific application, thin films of low-density polyethylene are the most widespread material used. The types of coverings currently available are dominated by plastics. Dilara and Briassoulis (2000) reported that, the most common tunnel glazing or covering material is polyethylene (PE) film. It is the least expensive glazing, with a low initial cost, and is reliable even with only a single layer.The high humidity will reduce plant transpiration, which influences growth and development. The free moisture from water vapor condensation on the PE and subsequent wetting of the crop from dripping can be a major concern for crop disease management. Kaiserand Ernst (2012) found that high tunnels do not have a permanent heating system; instead the air and ground within are passively solar-heated. Night time low air temperatures within a structure covered with two layers of plastic (with an insulating layer of air in between) can average about $-13.8^{\circ} \mathrm{c}$ to $-13.3^{\circ} \mathrm{c}$ warmer than outside temperatures. Structures covered with just a single layer of plastic often realize only a $-16.1^{\circ} \mathrm{c}$ increase in night time lows. Giacomelli et al. (1990) followed the techniques of co-extruding films and multi-layering of films during the extrusion process has been developed. These films offer even further opportunities for improved performance of the covering material. A double layer PE film tested at Rutgers Univ., later manufactured as "Cloud Nine" by the Monsanto Company (currently CT Films), and demonstrated a saving in night time supplemental heating of between $20 \%$ and $25 \%$ over the standard double-layer. Mulching is an agricultural practice commonly used for crop production since the mid1950s with among other benefits; weed control, soil moisture conservation and soil temperature regulation. Touchaleaume et al. (2016) reported that, squash seeds germination was affected by the soil covering treatments either by a black plastic mulch or straw. It is obvious that, seeds germinated in the covered soil trial (mulch or straw) faster and intensively compared with that of the bare soil under the same 
greenhouse. This refers to the covering effect which increased the soil temperature above that for the bare soil. Seeds germination ratios, plants growth, numbers of flowers in the covered soil trial (mulch or straw) were faster and intensively compared with that of the bare soil under the same greenhouse (Hassanain et al, 2008). Mulching films made of polyethylene (PE) have also been used for decades in long-term crops such as vineyards. However, non-biodegradable plastic mulch films ended up degrading in the field and progressively broke up into small pieces that are not recoverable at the end of the crop and consequently led to an irreversible and detrimental environmental contamination. Hence, biodegradable polymer films are more and more considered as ecofriendly alternatives to polyethylene (Briassoulis, 2007). The heating capability of the black mulch is greater as the degree of physical contact between mulch and soil surfaces increases. A black mulch, stretched tightly on the soil surface, absorbs most of the shortwave radiation, heats up and transfers energy to the soil more efficiently, mostly by conduction, than a loose-contact film (Bonachela et al, 2012). Awal and Ikeda (2002) studied four surface covering materials of $5 \mathrm{~cm}$ thick rice straw, a silver plastic film, a black plastic film and aclear plastic film were compared with bare ground as a control. They found that, the enhancement of cumulative emergence by increasing soil temperature was reflected in the rate of seedling emergence. The rate of seedling emergence significantly increased with increasing soil temperature and the emergence rates were positive linear functions of the soil temperatures the temperature increased rapidly in soil covered by clear film. The plastic cover affected the plant growth by decreasing days from planting to emergence and the maturity of many vegetable crops including tomato and cucumber. Mulching with crop residues improved water-use efficiency by $10-20 \%$ as a result of reduced soil evaporation and increased plant transpiration (Deng et al. 2006). Ramakrishna et al. (2006) found that, the polyethylene mulch increased the soil temperature. Groundnut plants in polyethylene and straw-mulched plots were generally tall, vigorous and reached early flowering. The world consumption of plastic materials in agriculture amounts yearly to 6.5 million tons, more than $10 \%$ of the total consumption refers to plastic 
films for soil mulching (Jouet, 2001). Yonggan Zhao et al. (2014) concluded that the combined application of straw mulchand buried straw layers had significant effects on soil moisture and salinity dynamics and sunflower growth. Throughout the three growing seasons, the combination of straw mulch with buried straw layer considerably increased the soil moisture at the $0-40 \mathrm{~cm}$ depth, except in the later growing period of the first season and significantly decreased the salinity of the topsoil layer $(0-20 \mathrm{~cm})$. Higher soil moisture and lower salinity in the root zone promoted sunflower growth.Straw mulch can conserve soil water and decrease temperature because it increases residue accumulation and reduces soil disturbance on the soil surface (Baumhardt and Jones 2002); Zhang et al., 2011). Mulch prevents soil water evaporation and thus helps retain soil moisture. Polythene and straw mulch treatments increased the pod and Stover yields of groundnut significantly over chemical and no-mulched treatments in both the seasons (Hu et al., 1995). Straw mulch is effective in improving soil physical conditions if it was used as organic amendment to the soil surface in tropical environments including protection of the top soil (Cook et al,. 2006). Reyes-Rosas et al. (2017) developed a model to predict temperatures of air, plants, greenhouse cover and soil in a naturally ventilated greenhouse with polypropylene mulch covering the soil in a Mediterranean climate. They found that on cloudy days, the change in the fraction of diffuse radiation produced the variation in the cover transmissivity, considered constant for each period in the model, on windy days, the climate control system closed the vent openings up to a point to prevent structural damage, thereby increasing heterogeneity of the inside air temperature. Under such circumstances, the temperature of air exiting the greenhouse via the openings was at a different temperature to the average inside air, invalidating the assumption of temperature uniformity and the reduction of air movement inside the greenhouse produces considerable heterogeneity in temperature distribution, with differences in temperature of about $7-8^{\circ} \mathrm{C}$ between the warm zones near the crop (cooling air by evapotranspiration) and very hot areas near the greenhouse cover in the middle of spans (where hot air accumulates due to the buoyancy effect). Lafont et al. (2015) reported that, greenhouse is a multi-input and multi- 
output system subject to strong perturbations produced by sudden meteorological variations that need to be taken into account in the models. The corresponding automated microclimate regulation should not only improve the production and its quality but also reduce pollution and energy consumption. The management of the greenhouse climate aims to maintain simultaneously a set of climatic factors such as the temperature, the hygrometry, and the rate of $\mathrm{CO}_{2}$ close to their respective references. Mesmoudi et al. (2010) found that the greenhouse soil is an important heat source during the night time, it can provide up to approximately $\left(44.03 \mathrm{~W} . \mathrm{m}^{-2}\right)$ in the case of a night preceded by a significant diurnal insulation. Compared with an artificial heating system, approximately 78 W. $\mathrm{m}^{-2}$, would be necessary under similar outside climatic conditions to maintain the temperature of the air inside the greenhouse between $15^{\circ}$ and $18^{\circ} \mathrm{C}$. Impron et al. (2007) reported that, the characterization of the energy balance of the greenhouses for each bioclimatic zone of the world becomes fundamental in order to evaluate the greenhouse feasibility, to improve its microclimate control (management and profitability), and to assess the effects of the latitude on the growth.

\section{OBJECTIVES}

Study of variable factors to control in environment surrounding plants to provide more suitable climatic conditions to maximize the final yield.

\section{MATERIALS AND METHODS}

The experiment was performed on Sidment village, graduates youth lands, Beni-sweif city, Egypt, (latitude angle of $29^{\circ} 5^{\prime} 8^{\prime \prime} \mathrm{N}$, longitude angle of $30^{\circ} 56^{\prime} 4^{\prime \prime} \mathrm{E}$ and $31 \mathrm{~m}$ above sea level). Through the period from 10 January 2016 till 15 April 2016, in order to investigate the most providing tunnel with optimum climatic conditions inside the polyethylene tunnel. A transparent polyethylene sheets of (40, 50, 65 micron) thick, single or double layers were used as tunnel covering sheets. The plane dimensions of each tunnel were $3 \mathrm{~m}$ long and $1 \mathrm{~m}$ wide and $60 \mathrm{~cm}$ height. The greenhouses tunnels were orientated toward theEast-West direction, where the southern longitudinal direction faced into the sun rays. The experimental duration was from January to April. We used multiple linear regressions to find the best tunnel that provides 
squash with optimum conditions to obtain maximum yield. Climatic parameters inside and outside the tunnel were recorded as following: Solar radiation by (solar power meter TENMARS-TM-207), temperature by (TENMARS-TM-747DUData-logging thermometer) with four sensors, inside relative humidity by (indoor/outdoor thermometer with hygrometer) and wind speed by meteorological station.
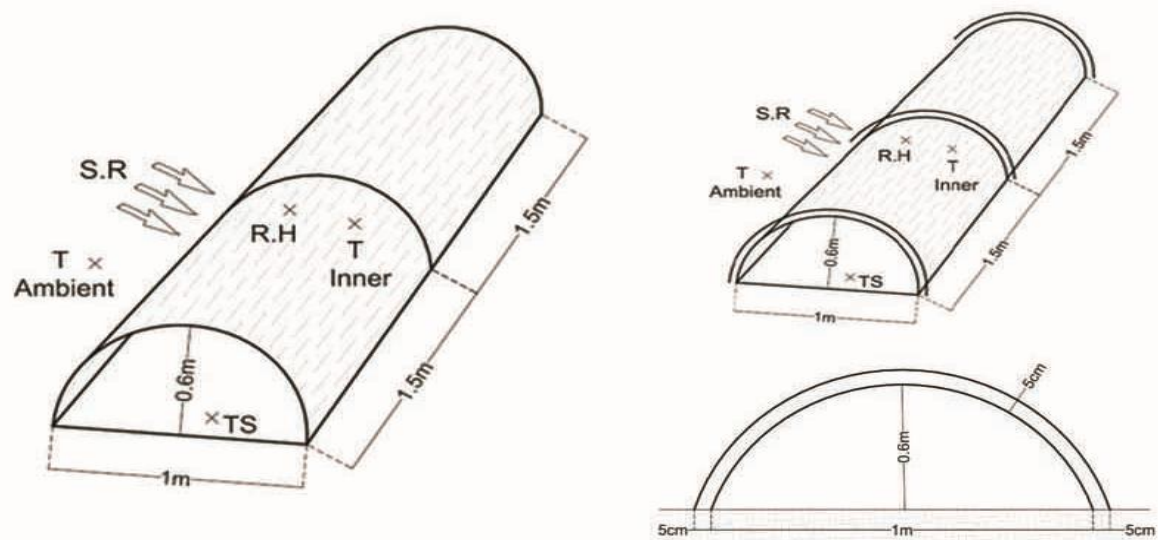

Fig. (1): structural design of tunnels with measured environmental data.

All of tunnels models under the same operation conditions such as soil, irrigation, fertilization, pest management, crop planted, tunnel design, tunnel orientation, ventilation system, distance between tunnels models, distance between plants, total ground area and number of plants per square meter. The variations between the tunnel models only were in cover thickness (40,50, 65 micron), covering soil with (rice straw $5 \mathrm{~cm}$ thickness, plastic mulch $0.1 \mathrm{~mm}$ thickness or bare soil), using single or double poly-ethylene tunnel cover layers, the distance between tunnel cover layers is $5 \mathrm{~cm}$ because of decreasing heat losses from the tunnel at night, to show their effects on inside air temperature, soil temperature, inside relative humidity and solar radiation intensity. Cattle manure of 15 $\mathrm{m}^{3}$ per fadden $\left(4200 \mathrm{~m}^{2}\right)$ was added during the preparation of root media inside the experimental greenhouses and in open field, this quantity is the recommended for squash, Cucurbita pepo L. (El-Shatoury, 2005). The squash crop following to cucurbitaceous family, this family sensitive to the temperature, reduction especially during the coldest night of winter time. Squash was hand planted in sapling with $50 \mathrm{~cm}$ distance between 
saplings. Experimental tunnels were irrigated using the farm drip irrigation system. Each treatment consisted of one lateral which included 5 emitters; the emitters were distributed at $0.5 \mathrm{~m}$ in apart. Squash was hand- planted in sapling with $50 \mathrm{~cm}$ distance between saplings during irrigation on 10 January 2016 due to the squash crop following to cucurbitaceous family. The ventilation system was a natural by lifting the plastic cover just on sunny days to extract over heat or over relative humidity from the tunnel and to save gases concentration inside the tunnel, in addition to help useful insects to do pollination process during flowering period. Ambient temperature $\left(\mathrm{Ta},{ }^{\circ} \mathrm{C}\right)$, solar radiation intensity $\left(\mathrm{I}, \mathrm{W} . \mathrm{m}^{-2}\right)$ and inner relative humidity (RH \%) were measured using a TENMARS-TM-747DU Data-logging thermometer with four thermocouples and indoor/outdoor thermometer with hygrometer. The air temperature and relative humidity were recorded daily for the period of study. Data were recorded at each one hour by the thermometer datalogger and hygrometer for all of the outside and inside air temperature, soil cover temperature and relative humidity. The effect of microclimatic conditions inside the tunnels on three growth stages (vegetation, flowering and fruit). Flowering measurement were taken every day from the begging flower appearance, squash crop yield were collected through the period of fruit stage from 11/2/2016 to 9/4/2016. Fruits were picked at three days intervals starting from crop mature day 23/2/2016 which number 43 from planting date. The fruits were picked up at accepted size for the local Egyptian customer in average weight of 110 grams. The total crop in $\mathrm{kg} /$ fadden was estimated for each treatment.

\section{Squash flowering stage:}

\section{RESULTS AND DISCUSSION}

Flowering was found affected by covering the soil with black plastic and straw mulch. It was found that, the number of flowers in the cultivated soil trial (plastic and rice straw) was faster and intensively comparing with that was cultivated in the bare soil under the same tunnel. The high number of flowers was given under the tunnel which cover thickness 50 micron with double layers of poly-ethylene with plastic mulched soil because of heat and mass balance that providing plants with suitable climatic conditions during plant flowering stage. 


\section{Single layer tunnel cover:}

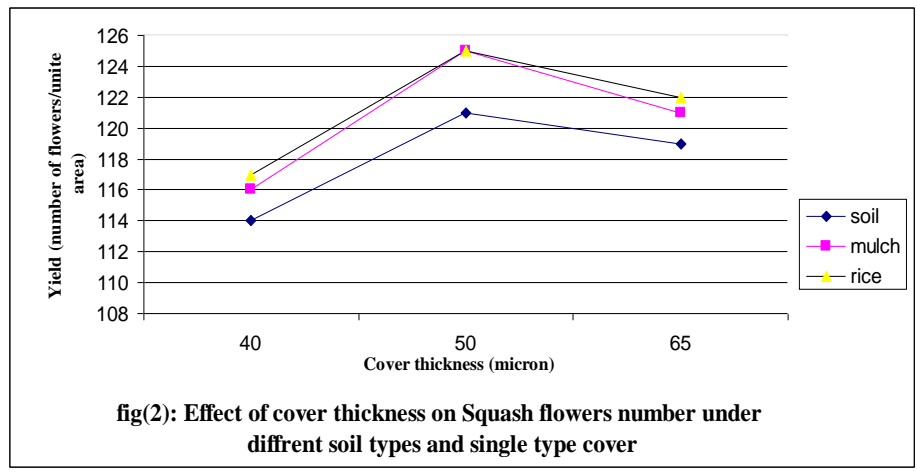

\section{Double layer tunnel cover:}

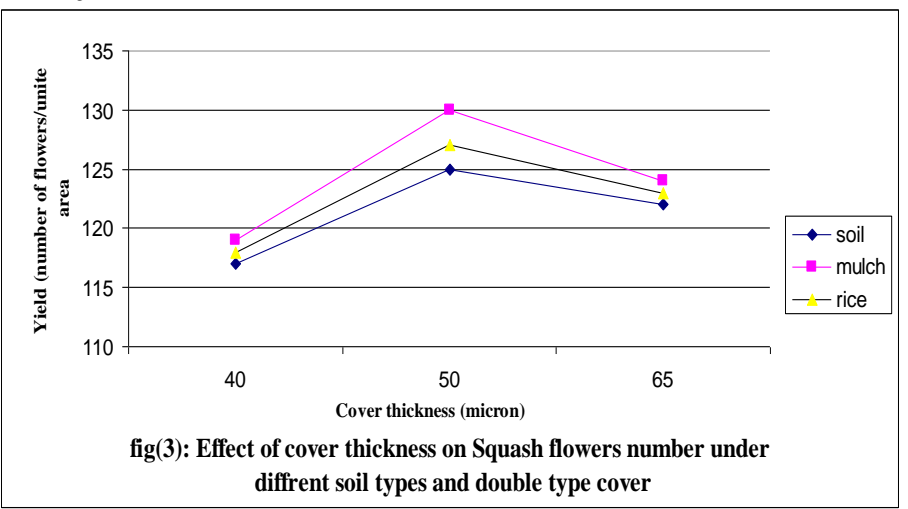

\section{Single layer tunnel cover:}

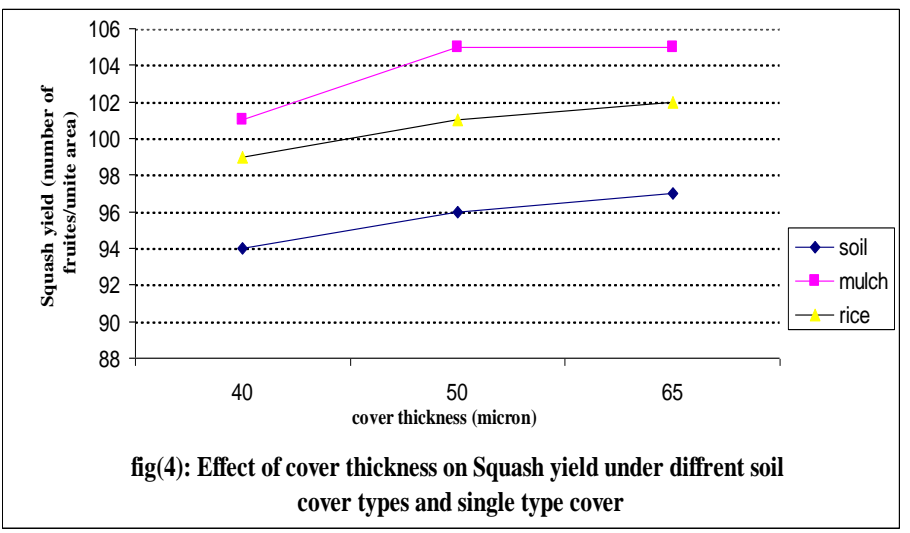

\section{Squash fruit stage:}

Total yield of squash crop depends on how much the squash plants were adapted to the investigated parameters. It was found that, the crop yield was higher for the tunnels with doubled layers cover and the soil 
covering treatments inside the greenhouse tunnel comparing with the single cover layer and the soil without cover.

Generally, increasing of squash yield as cover thickness increased as shown at Fig. (4). Case one, cover type is soil: squash yield increased by $2 \%$ with tunnel cover thickness increased from 40 to 50 micron, respectively, and squash yield increased $1 \%$ with tunnel cover thickness increased from 50 to 65 micron respectively. Case two, cover type is rice strew: squash yield increased $2 \%$ with tunnel cover thickness increased from 40 to 50 micron respectively, and squash yield increased from $1 \%$ with tunnel cover thickness increased from 50 to 65 micron respectively. Case three, cover type is mulch: squash yield increased by $4 \%$ with tunnel cover thickness increased from 40 to 50 micron respectively, on the other hand there isn't any increasing on squash yield with tunnel cover thickness increased from 50 to 65 micron. It's clear that, the best results of squash yield appeared with mulch soil cover type, where, squash yield increased by $7.4 \%, 9.5 \%$ and $8.2 \%$ with tunnel cover thickness of 40,50 and 65 micron, respectively.

\section{Double layer tunnel cover:}

Case one, cover type is soil: squash yield increased by $2 \%$ with tunnel cover thickness increased from 40 to 50 micron, respectively, and squash yield decreased by $1 \%$ with tunnel cover thickness increased from 50 to 65 micron respectively. Case two, cover type is rice straw: squash yield increased $2 \%$ with tunnel cover thickness increased from 40 to 50 micron respectively, and squash yield decreased by $1 \%$ with tunnel cover thickness increased from 50 to 65 micron respectively.

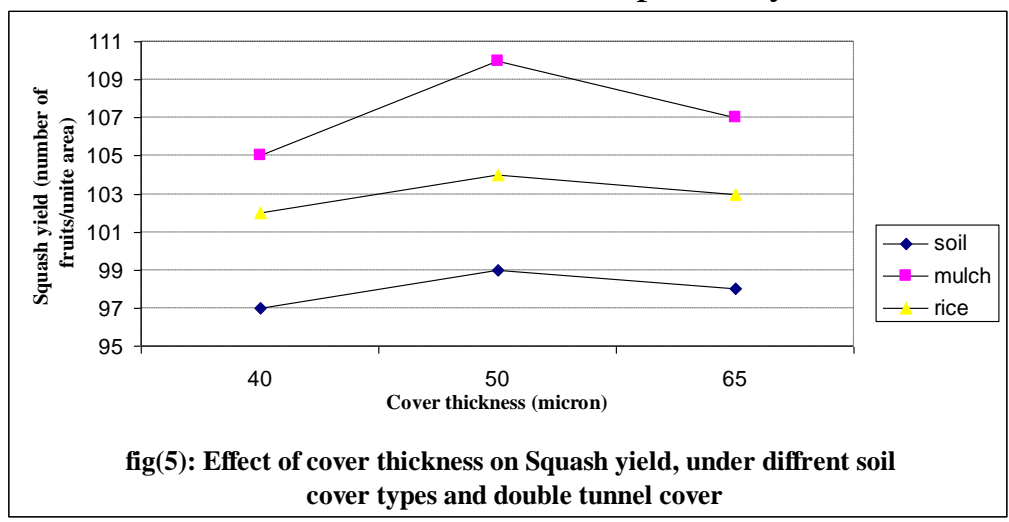


Case three, cover type is mulch: squash yield increased by $4.8 \%$ with tunnel cover thickness increased from 40 to 50 micron respectively, and squash yield decreased by $2.7 \%$ with tunnel cover thickness increased from 50 to 65 micron respectively. It's clear that, the best results of squash yield appeared with mulch soil cover type, where, squash yield increased by $8.2 \%, 11 \%$ and $9.2 \%$ with tunnel cover thickness of 40,50 and 65 micron, respectively.

\section{Effect of inner \& soil temperature on Squash yield:}

Fig. (6) shows the effect of inner and soil temperatures on squash yield. Two equations were developed to best fit. Exponential equations were resulted by excel software program to describe the relations between inner tunnel temperature $\left(T_{\text {in }}\right)$ and soil cover temperature $\left(T_{s}\right)$ with squash yield. The resulted equations were:

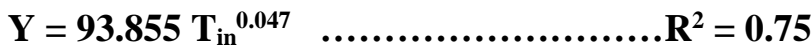

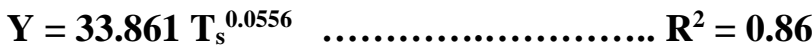

\section{Effect of inner relative humidity on Squash yield:}

Fig. (7) shows the effect of inner relative humidity on Squash yield. One equation was developed to best fit linear equation was resulted by excel software program to describe the relation between inner tunnel relative humidity $(\mathrm{Rh} \%)$ with squash yield. The resulted equation was:

$$
\mathrm{Y}=-\mathbf{3 . 9 0 3} \mathrm{Rh} 2+43.33 \mathrm{Rh}
$$
$\mathrm{R2}=\mathbf{0 . 5 3}$

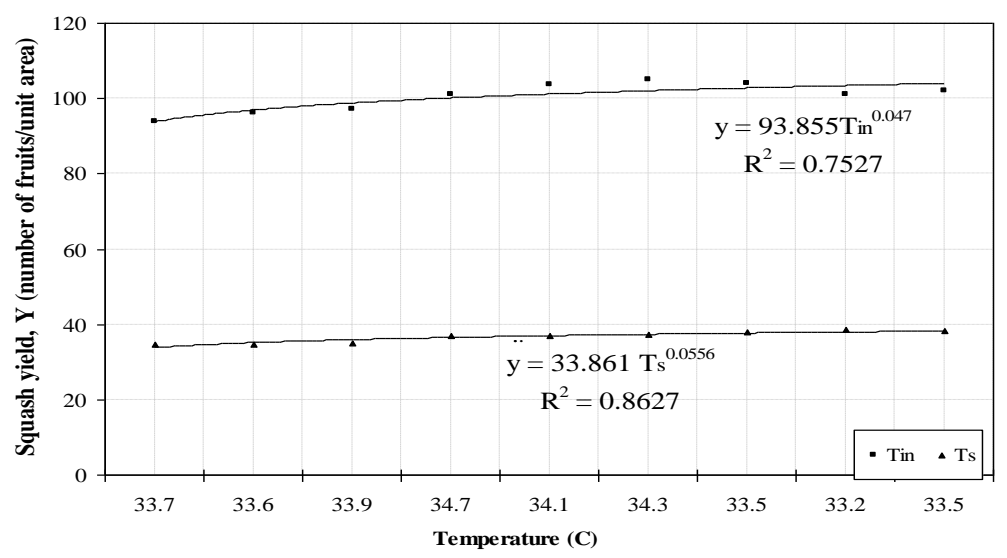

Fig. (6): Effect of temberature conditions on squash yield, under different soil cover types and single tunnel cover 


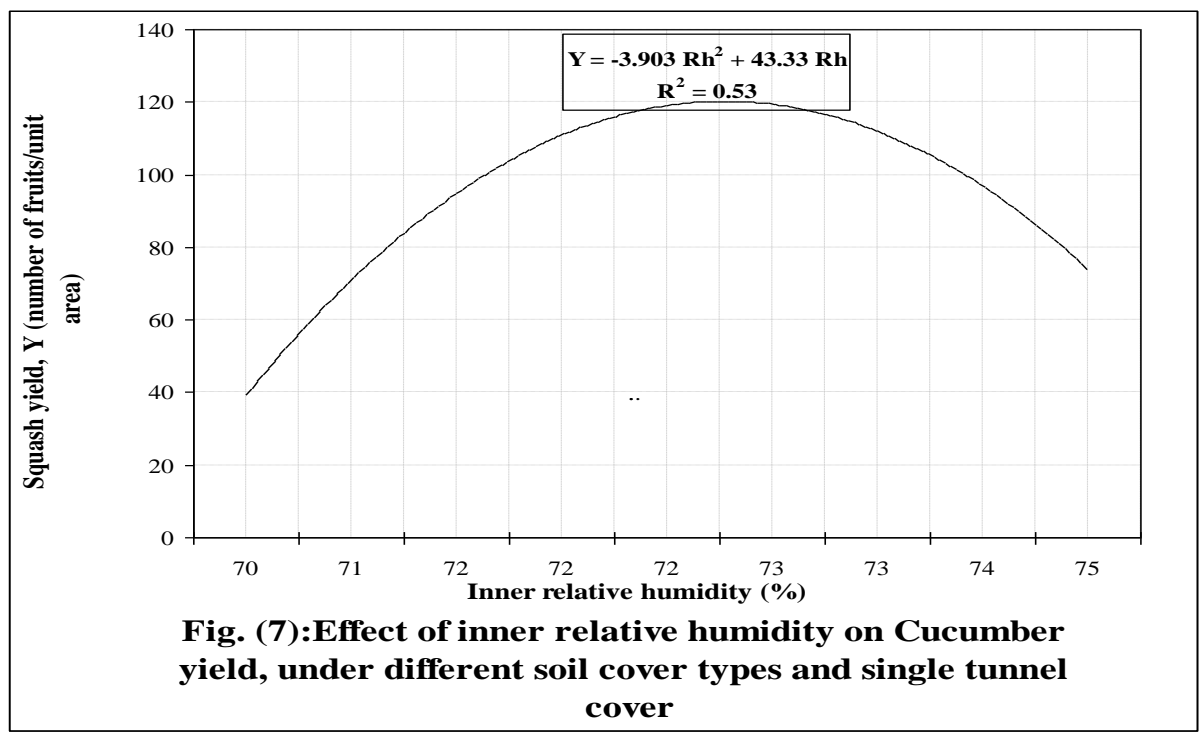

It shows that the maximum yield given with inner relative humidity between $72 \%$ and $73 \%$.

\section{CONCLUSIONS}

Growing of squash plants under the greenhouses tunnels were faster comparing with uncovered plants, this due to the heat storage that increased the tunnel air temperature surrounding plants. This was side by side with the effect of the soil covering type as the plant length was found highly affected by the soil covering treatments. The cultivated plants in the covered soil with black plastic mulch of $0.1 \mathrm{~mm}$ and the rice straw of 5 $\mathrm{cm}$ thickness were higher compared with the other uncovered soil under the same soil and inside the same greenhouse due to saving nutrients, surface soil temperature, irrigation efficiency and preventing weed competition. In addition to the tunnel cover thickness 40, 50, 65 micron and number of layers single, double layers also highly affected on plant growth and branching due to the amount of solar radiation transmission, thermal effect and photo selective effect.

\section{REFRENCES}

A.M. Abdel-Ghany, I.M. Al-Helal. 2011. Solar energy utilization by a greenhouse: General relations. Renewable Energy (36) 189-196. 
Abou-Hadid, A. F. 2000. The use of plastic in Egyptian greenhouses: an industrial challenge. The use of plastics in Agriculture, Alexandria, Egypt.

Audberto Reyes-Rosas, Francisco D. Molina-Aiz, Diego L. Valera, Alejandro López, SasirotKhamkure. 2017. Development of a single energy balance model for prediction of temperatures inside a naturally ventilated greenhouse with polypropylene soil mulch. Computers and Electronics in Agriculture, 142, 9-28.

Awa1, M.A. and T. Ikeda. 2002. Effects of changes in soil temperature on seeding emergence and phonological development in field-grown stands of peanut (Arachishypogaea).Environmental and Experimental Botany, Japan(47): 101-113.

Baumhardt, R.L., Jones, O.R., 2002. Residue management and tillage effects on soil-water storage and grain yield of dry land wheat and sorghum for a clay loam in Texas. Soil Tillage Res. 68, 71-82.

Bonachela, M.R. Granadosa, J.C. Lopez, J. Hernandez, J.J. Magan, E.J. Baeza, A. Baille. 2012. How plastic mulches affect the thermal and radiative microclimate in an unheated low-cost greenhouse. Agricultural and Forest Meteorology, 152, 65- 72.

Briassoulis, D. 2007. Analysis of the mechanical and degradation performances of optimized agricultural biodegradable films. Polymer Degradation and Stability 92, 1115-1132.

Cheryl Kaiser and Matt Ernst. 2012. High Tunnel Overview. Agriculture \& Natural Resources, pp. 1-7.

Cook, H.F., G.S. B. Valdes and H.C. Lee,.2006.Mulches effects on rainfall interception, soilphysical characteristics and temperature underZea mays L. Soil \&TillageResearch. (91), 227-235.

Deng, X., Shan, L., Zhang, H., Turner, N.C. 2006. Improving agricultural water use efficiency in arid and semi-arid areas of China. Agric. Water Manage. 80, 23-40. 
Dilara, P. A., Briassoulis, D., 2000. Degradation and Stabilization of Low-density Polyethylene Films used as Greenhouse Covering Materials. J. agric. Engng Res.76, 309-321.

El-Shatoury, R. S., 2005. Effects of the plants density and nitrogenous fertilizer on growth characters of summer squash, Master of Science, Horticulture department, Faculty of Agriculture, Suez Canal University, Egypt.

Elsner, B. von ; Briassoulis, D; Waaijenberg, D; Mistriotis, A; Zabeltitz Chr. von; Gratraud, J ; Russo, G; Suay-Cortes, R. 2000. Review of Structural and Functional Characteristics of Greenhouses in European. Union Countries: Part I, Design Requirements. J. agric. Engng Res. 75, 1-16.

François Touchaleaume, Lluís Martin-Closas, Helene AngellierCoussy, Anne Chevillard, Guy Cesar, Nathalie Gontard, Emmanuelle Gastaldi. 2016. Performance and environmental impact of biodegradable polymers as agricultural mulching films. Chemosphere, 144, 433-439.

Giacomelli, G.A., K.C. Ting, and W. Fang. 1990.Wavelength specific transmission of polyethylene film greenhouse glazing. Agr. Plastics Congr.(22): 129-134.

Hassanain, A.A , Elsayed, A.S, and Kishk, S.A. 2008. Solar Storage Wall and Soil Mulching Effect on Squash Production Inside Polyethylene Greenhouse under the Climate of Egypt. AmericanEurasianJ.Agric.\&Environ.Sci.,3(6):906-916.

Hu, W., Duan, S. and Sui, Q. 1995. Highyield technology for groundnut Int. Arachis Newsletter,15,1-22.

Jouet, J.P.2001. Plastics in the world. Plasticulture., 120(2): 26108.

KamelMesmoudi, AzzedineSoudani, BarizaZitouni, P.E. Bournet, LazharSerir. 2010. Experimental study of the energy balance of 
unheated greenhouse under hot and arid climates: study for the night period of winter season. Journal of the Association of Arab Universities for Basic and Applied Sciences, 9, 27-37.

Lafont, F., Balmat, J.F., Pessel., N., Fliess, M., N., Fliess, M., 2015. A model-free control strategy for an experimental greenhouse with an application to fault accommodation. Comput. Electron. Agricult. 110, 139-149.

Ramakrishna, A., H.M. Tann, S.P. Waniand T.D. Long, 2006. Effect of mulch on soil temperature, moisture, weed infestation and yield of groundnut in northern Vietnam. Field Crop Research, 95:115-125.

Yonggan Zhao, Huancheng Pang, Jing Wang, Long Huo, Yuyi Li. 2014. Effects of straw mulch and buried straw on soil moisture and salinity in relation to sunflower growth and yield. Field Crops Research. 161, 16-25.

Zhang, S.L., Lövdahl, H., Grip, Y.A., Shuqin, W., Wei, H., Shiping, L., Shuhui, L., 2011.Salt distribution and the growth of cotton under different drip irrigation regimes in a saline area. Agric. Water Manag. 100, 58-69.

$$
\begin{aligned}
& \text { الملخص العربي } \\
& \text { أداء الانفاق الزراعية المنخفضة لإنتاج الخضروات }
\end{aligned}
$$

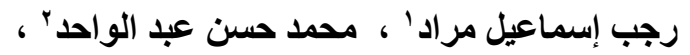

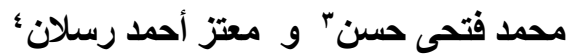

تستخدم الإنفاق الزراعية للتحكم في الظروف البيئية المحيطة بالنباتات لتوفير المناخ المناسب

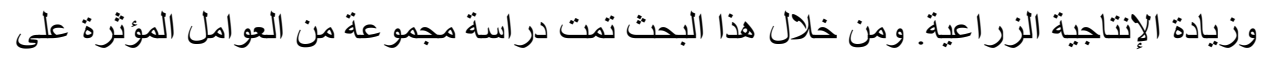

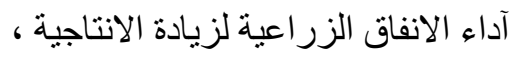

$$
\begin{aligned}
& \text { 'أستاذ الهندسة الزراعية ـ كلية الزراعة بمطروح - جامعة الاسكندرية. }
\end{aligned}
$$

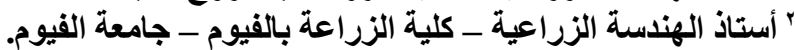

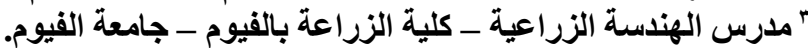

$$
\begin{aligned}
& \text { " مهندس زراعي بشركة شوري للكيماويات. }
\end{aligned}
$$




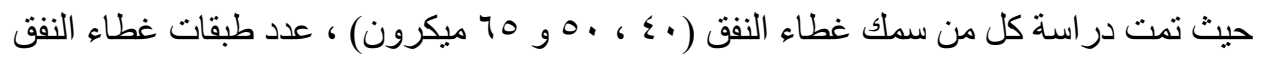

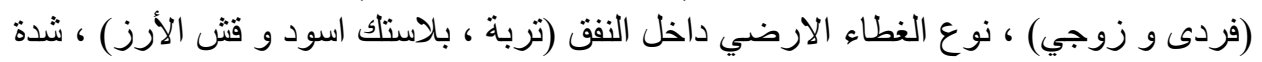

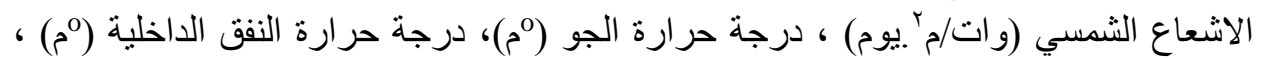

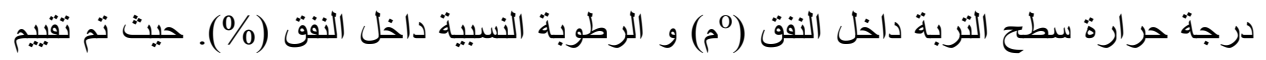
أداء النفق من خلال إنتاجية محصول القرع (Cucurbita) وكفاءة آداء النفق الحر ارية.

وقد أظهرت النتائج ان أقصى إنتاجية من القرع كانت مع المواصفات التالية (تربة مغطاة

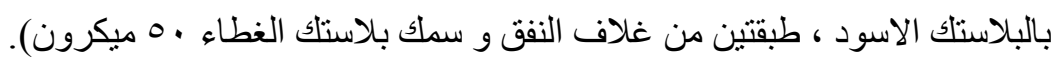

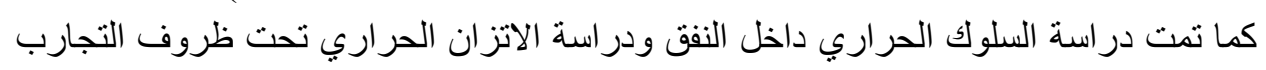
المختلفة. 